\title{
Use of Belowground Growing Degree Days to Predict Rooting of Dormant Hardwood Cuttings of Populus
}

\author{
By R. S. ZALesny JR. ${ }^{1}$, E. O. BAUER and D. E. Riemenschneider
}

USDA Forest Service, North Central Research Station, Forestry Sciences Laboratory, 5985 Highway K, Rhinelander, WI 54501

(Received $10^{\text {th }}$ September 2004)

\begin{abstract}
Planting Populus cuttings based on calendar days neglects soil temperature extremes and does not promote rooting based on specific genotypes. Our objectives were to: 1) test the biological efficacy of a thermal index based on belowground growing degree days (GDD) across the growing period, 2) test for interactions between belowground GDD and clones, and 3) identify beneficial planting windows based on combinations of genotypes and belowground GDD. We tested two clones of Populus deltoides Bartr. ex Marsh (D133, D134) and four hybrid clones of $P$. deltoides x P. maximowiczii A. Henry (DM101, DM105, NC14105, NC14107). Cuttings, $20 \mathrm{~cm}$ long, were planted in randomized complete blocks at $15-\mathrm{x} 15-\mathrm{cm}$ spacing across three planting dates during 1999 at Alexandria, Minnesota, USA $\left(45.9^{\circ} \mathrm{N}, 95.4^{\circ} \mathrm{W}\right)$ and Fertile, Minnesota, USA $\left(47.3^{\circ} \mathrm{N}\right.$, $96.2^{\circ} \mathrm{W}$ ). Temperatures at $20 \mathrm{~cm}$ belowground were converted to GDD with a base temperature of $10^{\circ} \mathrm{C}$. We measured root, top, and total dry weight, along with number of roots after $14 \mathrm{~d}$ of growth. Relatively warmer and cooler soil temperatures promoted rooting for the cottonwoods and hybrids, respectively. We recommend planting after reaching a threshold of 163 belowground GDD for $P$. deltoides clones and planting before reaching a threshold of 173 belowground GDD for P. deltoides $\mathrm{x}$ P. maximowiczii clones.
\end{abstract}

Key words: Populus deltoides, P. maximowiczii, hybrid poplar, soil temperature, genotype $\mathrm{x}$ environment interaction.

\section{Introduction}

Selected genotypes within the genus Populus have been used in short rotation intensive culture throughout Europe and North America for decades (DiCKMANN, 2001). Poplar plantations have become increasingly important in the North Central United States because of a predicted shortage of quaking aspen (P. tremuloides Michx.) and bigtooth aspen ( $P$. grandidentata Michx.) within 10 to 20 years (PIva, 2003; Husain et al., 1998). Poplars are planted on a prepared site for primary uses such as fiber production, energy (biomass for electricity and liquid fuels), phytoremediation, agroforestry, and raw material for engineered lumber products (ISEBRANDS and KARNOSKY, 2001; HeIlman, 1999; Tolbert and Wright, 1998). Breeding and selecting poplar clones for rooting ability is a component of research conducted to identify poplar genotypes adapted to regional environments (RIEMENSCHNEIDER et al., 2001).

The propagule of choice in the North Central region is an unrooted dormant hardwood cutting (RIEMENSCHNEIDER and BAUER, 1997). The ability of poplars to form adventitious roots is therefore critical to the commercial deployment of intensively cultured poplar plantations (DiCKMANN, 2001; STANTURF et al., 2001). Rooting is often genotype-dependent (ZALESNY et al., 2003; Ying and BAGLeY, 1977; CunNingham, 1953); however, the success of plantation establishment also depends on the

\footnotetext{
1) Corresponding author is a research plant geneticist at: USDA Forest Service, North Central Research Station, Forestry Sciences Laboratory, 5985 Highway K, Rhinelander, WI 54501. Phone: (715) 362-1132; Fax: (715) 362-1166; Email: rzalesny@fs.fed.us.
}

influence of genotype $x$ environment interactions (HEILMAN et al., 1994; HAISSIG et al., 1992). Belowground environmental conditions such as soil temperature, moisture, strength, and aeration influence the success of rooting from dormant hardwood cuttings (DesRochers et al., 2002; RHodenbaugh and Pallardy, 1993; Wiersum, 1980). The most common soil temperature threshold for planting poplars is $10^{\circ} \mathrm{C}$ (LANDHÄUSSER et al., 2001; WAN et al., 1999; HANSEN et al., 1983). However, fluctuations in soil temperatures at a depth of $20 \mathrm{~cm}$ during any given 24-hour period deem it unrealistic to base the time of planting solely on a temperature threshold. Therefore, alternative protocols are needed.

One potential protocol is to base planting on a thermal index such as the accumulation of belowground growing degree days (GDD), which also has been used in the plant sciences to predict growth, harvest dates, insect outbreaks, and other biological phenomena (CASTELAN-EstradA et al., 2002; LoBit et al., 2001; Cox and Malcolm, 1997). An index based on GDD includes temperature extremes associated with erratic weather conditions and is, therefore, preferable to an index based on calendar day (LUOMAJOKI, 1995). Growing degree days are defined as the sum of the average temperature in a 24-hour period minus a base temperature, where the base temperature equals a threshold that supports adequate plant growth (LU et al., 2001; VINOCUR and RITCHIE, 2001; NEWMAN et al., 1968), over a specified period of time. A commonly accepted base temperature in the North Central region is $10^{\circ} \mathrm{C}$ (HANSEN, 1986; HANSEN et al., 1983; JENKINSON, 1980). A poplar-rooting index based on belowground GDD is obtained by summing the daily belowground GDD during the period from planting until harvesting. Soil temperature data have been converted to belowground GDD in an attempt to identify planting windows that promote rooting, based on the genotype being used (ZALESNY, 2003). The identification of such planting windows for specific combinations of genotypes and belowground GDD could increase the success of plantation establishment, which ultimately could reduce pressure on native stands of aspen.

The objectives of this study were to: 1) test the biological efficacy of a thermal index that was based on the accumulation of belowground GDD across the growing period, 2) test for interactions between belowground GDD and clones, and 3) identify planting windows based on combinations of genotypes and belowground GDD that promote rooting from dormant hardwood cuttings.

\section{Materials and Methods \\ Clone and site selection}

Two clones (D133, D134) of eastern cottonwood origin (P. deltoides) and four clones (DM101, DM105, NC14105, NC14107) of hybrid origin ( $P$. deltoides $\times$ P. maximowiczii) were sampled at random from two populations during January of 1999. The populations were selected based on their variable growth potential and anticipated range of rooting abilities. Cuttings, $20 \mathrm{~cm}$ long, were processed from whips collected in stool beds 
established at Hugo Sauer Nursery in Rhinelander, Wisconsin, USA $\left(45.6^{\circ} \mathrm{N}, 89.4^{\circ} \mathrm{W}\right)$. Two primary buds were positioned not more than $2.54 \mathrm{~cm}$ from the top of each cutting. Cuttings were stored in polyethylene bags at $3^{\circ} \mathrm{C}$ until they were soaked in water for $3 \mathrm{~d}$ before planting. There were three planting dates at each of two sites [Alexandria, Minnesota, USA $\left\{45.9^{\circ} \mathrm{N}\right.$, $\left.95.4^{\circ} \mathrm{W}\right\}$; Fertile, Minnesota, USA $\left.\left\{47.3^{\circ} \mathrm{N}, 96.2^{\circ} \mathrm{W}\right\}\right]$ during May and June of 1999. The planting dates were chosen for establishment at different soil temperatures during the beginning of the growing season. Test plots were deep tilled before planting. The experimental design was randomized complete blocks with two blocks per planting date and five ramets per clone per block. Spacing was $15 \times 15 \mathrm{~cm}$ between cuttings.

Environmental data were collected at 5-minute intervals throughout each 14-d growing period. $\mathrm{HOBO}^{\circledR} \mathrm{H} 8$ Pro Series data loggers (Onset Corporation, Bourne, Massachusetts) were used to record relative humidity and ambient temperature in the shade at $1 \mathrm{~m}$ above the soil surface and soil temperature at $20 \mathrm{~cm}$ below the soil surface. Precipitation data were recorded weekly.

\section{Data analysis}

The cuttings were harvested $14 \mathrm{~d}$ after planting and roots were washed and counted. Lateral roots, leaves, stems, callus, and callus roots were dissected from each cutting, bagged, and dried at $70^{\circ} \mathrm{C}$ for dry weight determination. Callus and callus root production were negligible, and therefore were not considered in the analysis. Root dry weight, number of roots, top (shoot plus leaves) dry weight, total plant dry weight, and cutting dry weight were evaluated.

Data were subjected to analysis of variance according to SAS $^{\circledR}$ (PROC GLM; SAS InstituTe, InC., 2000) assuming all random effects. Non-significant $(\alpha \geq 0.25)$ interaction terms from the original all-effects model were pooled with the residual error term to increase precision of F-tests. Cutting dry weight ranged from 2.5 to $14.8 \mathrm{~g}$ and was a significant $(P \leq 0.05)$ covariate in the analysis. Final means were adjusted to account for this variation in cutting dry weight. Fisher's protected least significant difference (LSD) was used to separate means of main effects when no higher-order interactions were present.

$$
\begin{aligned}
& \mathrm{GDD}=\sum \mathrm{GDD}=\sum\left[\left(\frac{T_{\max }+\mathrm{T}_{\text {min }}}{2}\right)-\mathrm{T}_{\mathrm{b}}\right] \\
& \mathrm{Y}_{\mathrm{ijk} \mathrm{km}}=\mu+\mathrm{S}_{\mathrm{i}}+\mathrm{G}_{(\mathrm{i}) \mathrm{j}}+\mathrm{B}_{(\mathrm{ij}) \mathrm{k}}+\mathrm{C}_{1}+\mathrm{SC}_{\mathrm{il}}+\mathrm{GC}_{(\mathrm{i}) \mathrm{j} 1}+\mathrm{E}_{(\mathrm{ijk} k) \mathrm{m}}
\end{aligned}
$$

Soil temperatures across each planting date were converted to belowground GDD. The GDD index used for each 14-d growing period is defined in $\{1\}$, where: $\mathrm{T}_{\max }$ and $\mathrm{T}_{\min }=$ maximum and minimum soil temperature at a depth of $20 \mathrm{~cm}$, respectively, and $\mathrm{T}_{\mathrm{b}}=$ the base temperature of $10^{\circ} \mathrm{C}$. For daily mean temperatures less than $\mathrm{T}_{\mathrm{b}}=10^{\circ} \mathrm{C}$, the belowground GDD were recorded as zero. A factor designated growing degree day $(\mathrm{G})$ was used in lieu of planting date in the linear additive model defined in $\{2\}$, where: $\mathrm{Y}_{\mathrm{ijk} k \mathrm{~m}}=$ response variable to be analyzed from $\mathrm{m}^{\text {th }}$ experimental unit, $\mu=$ overall mean, $S_{i}=$ main effect of $i^{\text {th }}$ site (random), $G_{(\mathrm{ijj})}=$ main effect of $j^{\text {th }}$ belowground GDD estimation nested within $\mathrm{i}^{\text {th }}$ site (random), $\mathrm{B}_{(\mathrm{ij}) \mathrm{k}}=$ main effect of $\mathrm{k}^{\text {th }}$ block nested within $\mathrm{i}^{\text {th }}$ site and $\mathrm{j}^{\text {th }}$ belowground GDD estimation (random), $\mathrm{C}_{1}=$ main effect of $\mathrm{l}^{\text {th }}$ clone (random), $\mathrm{SC}_{\mathrm{il}}=$ effect of 2-way interaction between $\mathrm{i}^{\text {th }}$ site and $\mathrm{l}^{\text {th }}$ clone, $\mathrm{GC}_{(\mathrm{i}) \mathrm{j} \mathrm{l}}=$ effect of 2-way interaction between $j^{\text {th }}$ belowground GDD estimation nested within $\mathrm{i}^{\text {th }}$ site and $\mathrm{l}^{\text {th }}$ clone, and $\mathrm{E}_{(\mathrm{ijkl}) \mathrm{m}}=$ pooled experimental error associated with $\mathrm{m}^{\text {th }}$ experimental unit, NID $\left(0, \sigma^{2}\right)$.

$$
\begin{aligned}
& H_{\text {general }}=\left(\frac{\sigma_{\text {genorypic }}^{2}}{\sigma_{\text {pherartypic }}^{2}}\right)=\left(\frac{\sigma_{\mathrm{G}}^{2}}{\sigma_{\mathrm{G}}^{2}+\sigma_{\mathrm{GE}}^{2}+\sigma_{\mathrm{E}}^{2}}\right) \\
& H_{\text {specific }}=\left[\frac{\sigma_{\mathrm{C}}^{2}}{\sigma_{\mathrm{C}}^{2}+\left(\sigma_{\mathrm{SC}}^{2}+\sigma_{\mathrm{GC}}^{2}\right)+\sigma_{\mathrm{E}}^{2}}\right]
\end{aligned}
$$

Variance components were determined by using method of moments estimation in PROC VARCOMP of SAS ${ }^{\circledR}$ (SAS INSTITUTE, INC., 2000). The variance estimates were used to estimate broad-sense heritability $(H)$, the percentage of phenotypic variation among clones due to combined genetic effects, on an individual-tree basis, according to WILCOX and FARMER (1968). The general form of the model used to estimate $H$ is defined in $\{3\}$, where: $\sigma_{G}^{2}=$ genotypic variance attributed to genetic differences among clones, $\sigma_{\mathrm{GE}}^{2}=$ variance attributed to genotype $\mathrm{x}$ environment interaction, and $\sigma_{\mathrm{E}}^{2}=$ environmental variance attributed to experimental error. The specific model used to estimate $H$ is defined in $\{4\}$, where: $\sigma_{C}^{2}=$ genotypic variance attributed to genetic differences among clones, $\sigma_{\mathrm{SC}}^{2}=$ variance attributed to site $x$ clone interaction, $\sigma_{\mathrm{GC}}^{2}=$ variance attributed to belowground GDD $x$ clone interaction, and $\sigma_{E}^{2}=$ environmental variance attributed to experimental error.

$$
\begin{aligned}
& r_{\mathrm{G}}=\left(\frac{\sigma_{\mathrm{GXV}}}{\sigma_{\mathrm{GX}} \sigma_{\mathrm{GY}}}\right) \\
& r_{\mathrm{E}}=\left(\frac{r_{\mathrm{p}}}{\sqrt{1-H_{\mathrm{X}}} \sqrt{1-I_{\mathrm{Y}}}}\right)-\left(\frac{r_{\mathrm{G}} h_{\mathrm{X}} h_{\mathrm{Y}}}{\sqrt{1-I_{\mathrm{X}}} \sqrt{1-H_{\mathrm{Y}}}}\right)
\end{aligned}
$$

Phenotypic correlations $\left(r_{\mathrm{p}}\right)$ were determined using Pearson's correlation coefficients generated by the PROC CORR statement of SAS $^{\circledR}$ (SAS Institute, InC., 2000). A multivariate
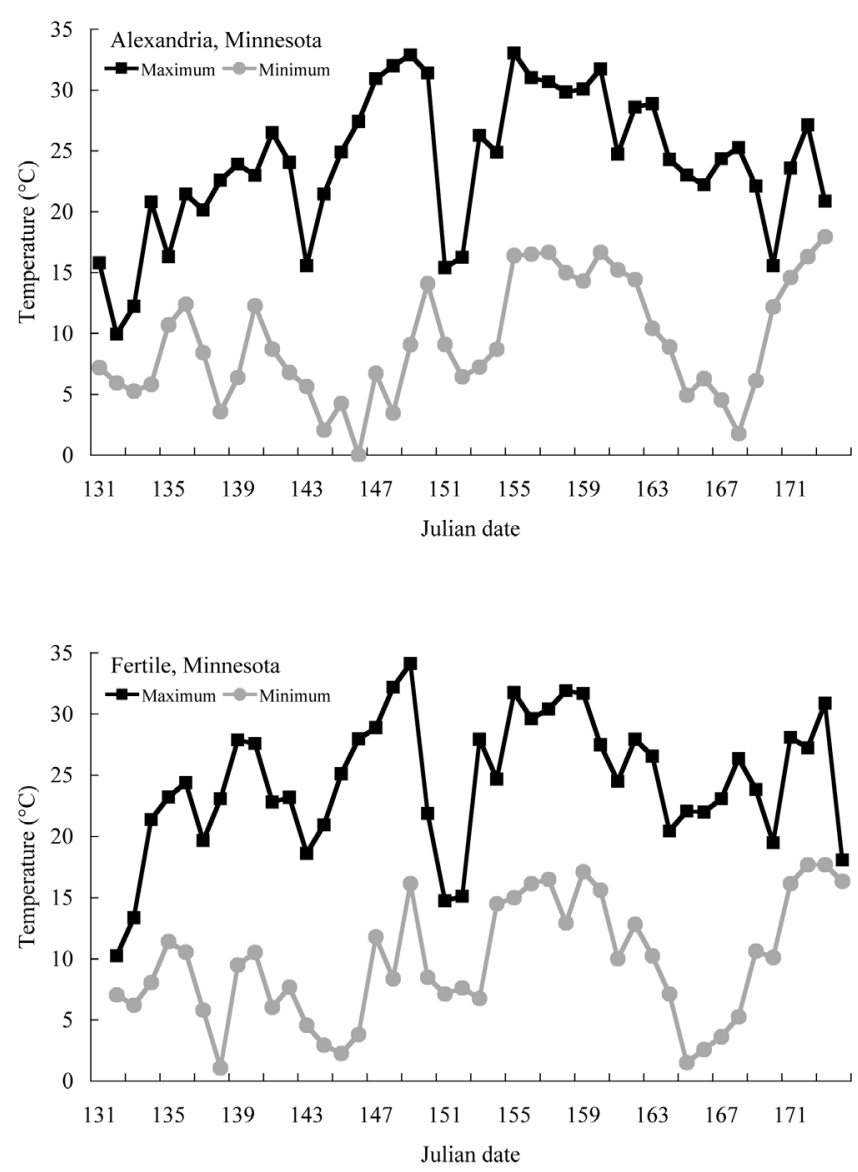

Figure 1. - Maximum and minimum temperatures at $20 \mathrm{~cm}$ below the soil surface during the period of the study in 1999 at Alexandria, Minnesota, and Fertile, Minnesota. 
Table 1. - Phenotypic correlations ${ }^{\mathrm{a}}$ among root dry weight, number of roots, top dry weight, and total dry weight $14 \mathrm{~d}$ after planting. All correlations significant at $P<0.0001$

\begin{tabular}{|c|c|c|c|c|}
\hline & Root dry weight & Number of roots & Top dry weight & Total dry weight \\
\hline Root dry weight & & 0.67 & 0.43 & 0.57 \\
\hline Number of roots & & & 0.36 & 0.44 \\
\hline Top dry weight & & & & 0.99 \\
\hline
\end{tabular}

a Phenotypic correlations generated by using PROC CORR of SAS ${ }^{\circledR}$ (SAS INSTITUTE, INC., 2000).

Table 2. - Genotypic (above diagonal) and environmental (below diagonal) correlations ${ }^{\mathrm{a}}$ among root dry weight, number of roots, top dry weight, and total dry weight $14 \mathrm{~d}$ after planting.

\begin{tabular}{lcccc}
\hline & Root dry weight & Number of roots & Top dry weight & Total dry weight \\
\hline Root dry weight & & 0.94 & 0.79 & 0.85 \\
Number of roots & 0.62 & & 0.97 & 0.99 \\
Top dry weight & 0.36 & 0.22 & & 1.00 \\
Total dry weight & 0.51 & 0.31 & 0.99 & \\
\hline
\end{tabular}

a Estimation of genotypic and environmental correlations adapted from FALCONER and MACKAY (1989). analysis of variance procedure in PROC GLM of $\mathrm{SAS}^{\circledR}$ (SAS INSTITUTE, INC., 2000) was used to generate sums of squares and cross products, which were used for estimation of genetic $\left(r_{\mathrm{G}}\right)$ and environmental $\left(r_{\mathrm{E}}\right)$ correlations. The specific model used to estimate $r_{\mathrm{G}}$ is defined in $\{5\}$, where: $\sigma_{\mathrm{GxY}}=$ genotypic covariance between $\mathrm{X}$ and $\mathrm{Y}, \sigma_{\mathrm{GX}}=$ square root of the genotypic variance of $\mathrm{X}$, and $\sigma_{\mathrm{GY}}=$ square root of the genotypic variance of Y. Adapted from FALCONER and MACKAY (1989), the specific model used to estimate $r_{\mathrm{E}}$ is defined in $\{6\}$, where: $r_{\mathrm{P}}=$ phenotypic correlation between characters $\mathrm{X}$ and $\mathrm{Y}, r_{\mathrm{G}}=$ genetic correlation between characters $\mathrm{X}$ and $\mathrm{Y}, H_{\mathrm{X}}=$ broad-sense heritability of character $\mathrm{X}, H_{\mathrm{Y}}$ = broad-sense heritability of character $\mathrm{Y}, h_{\mathrm{X}}=$ square root of $H_{\mathrm{X}}$, and $h_{\mathrm{Y}}=$ square root of $H_{\mathrm{Y}}$.

\section{Results}

Temperatures at $20 \mathrm{~cm}$ below the soil surface during the period of study in 1999 ranged from 0 to $33^{\circ} \mathrm{C}$ and 1 to $34^{\circ} \mathrm{C}$ at Alexandria, Minnesota, and Fertile, Minnesota, respectively (Figure 1). These data demonstrate the broad variation in soil temperatures for the three planting dates at each site. The accumulation of belowground GDD for each 14-d growing period ranged from 84 to 294 .

Broad-sense heritability estimates for root dry weight and number of roots were 0.15 and 0.19 , respectively. Likewise, heritabilities for top dry weight and total dry weight were 0.18

Table 3. - Analysis of variance mean squares and expected mean squares in an experiment testing clones of two populations of Populus $[P$. deltoides and $\{$. deltoides $\times$ P. maximowiczii $\}]$ for differences in root dry weight, number of roots, top dry weight, and total dry weight when planted as dormant hardwood cuttings.

Probabilities associated with $\mathrm{F}$ variance-ratios are listed within parentheses, with significant $(\alpha \leq 0.05)$ ratios in bold. GDD = belowground growing degree days.

\begin{tabular}{|c|c|c|c|c|c|c|}
\hline \multirow[t]{2}{*}{ Source } & \multicolumn{2}{|l|}{ df } & \multicolumn{2}{|c|}{ Mean squares } & \multicolumn{2}{|r|}{ Expected mean squares $^{\mathrm{a}, \mathrm{b}}$} \\
\hline & & Root dry & Number & Top dry & Total dry & \\
\hline & & weight (mg) & of roots & weight (mg) & weight (mg) & \\
\hline \multirow[t]{2}{*}{ Site } & 1 & 0.17 & 42.71 & 162.83 & 173.49 & $\sigma^{2}+10 \sigma_{\mathrm{GC}}^{2}+30 \sigma_{\mathrm{SC}}^{2}+30 \sigma_{\mathrm{B}}^{2}+$ \\
\hline & & $(0.7707)$ & $(0.8246)$ & $(0.3235)$ & $(0.3030)$ & $60 \sigma_{G}^{2}+180 \sigma_{S}^{2}$ \\
\hline \multirow[t]{2}{*}{ GDD(Site) } & 4 & 1.90 & 801.17 & 128.60 & 124.21 & $\sigma^{2}+10 \sigma_{\mathrm{GC}}^{2}+30 \sigma_{\mathrm{B}}^{2}+60 \sigma_{\mathrm{G}}^{2}$ \\
\hline & & $(0.4356)$ & $(0.0071)$ & $(0.0732)$ & $(0.1137)$ & \\
\hline \multirow[t]{2}{*}{ Block(GDD Site) } & 6 & 1.16 & 41.74 & 33.18 & 39.58 & $\sigma^{2}+30 \sigma_{B}^{2}$ \\
\hline & & $(0.0334)$ & $(0.3519)$ & $(0.0170)$ & $(0.0181)$ & \\
\hline \multirow[t]{2}{*}{ Clone } & 5 & 6.80 & 766.10 & 186.18 & 246.51 & $\sigma^{2}+10 \sigma_{\mathrm{GC}}^{2}+30 \sigma_{\mathrm{SC}}^{2}+60 \sigma_{\mathrm{C}}^{2}$ \\
\hline & & $(0.0200)$ & $(0.0208)$ & $(0.0082)$ & $(0.0073)$ & \\
\hline \multirow[t]{2}{*}{ Site*Clone } & 5 & 0.85 & 98.16 & 15.52 & 19.55 & $\sigma^{2}+10 \sigma_{\mathrm{GC}}^{2}+30 \sigma_{\mathrm{SC}}^{2}$ \\
\hline & & $(0.6213)$ & $(0.6719)$ & $(0.4793)$ & $(0.4920)$ & \\
\hline \multirow[t]{2}{*}{ GDD(Site)*Clone } & 20 & 1.20 & 153.37 & 16.59 & 21.39 & $\sigma^{2}+10 \sigma_{\mathrm{GC}}^{2}$ \\
\hline & & $(0.0008)$ & $(<0.0001)$ & $(0.1692)$ & $(0.1187)$ & \\
\hline Error & 318 & 0.50 & 37.36 & 12.65 & 15.26 & $\sigma^{2}$ \\
\hline Total & 359 & & & & & \\
\hline $\begin{array}{l}\text { Type III expecte } \\
\text { PROC GLM of } \\
\sigma_{-}^{2}=\text { variance } \\
\sigma^{2}{ }_{B}=\text { block nes } \\
\text { ground GDD*clo }\end{array}$ & $\begin{array}{l}\text { d mea } \\
\text { AS }^{\circledR} \\
\text { attribu }\end{array}$ & $\begin{array}{l}\text { squares an } \\
\text { AS INSTITUTH } \\
\text { ted to term } \\
\text { thin site an } \\
=\text { error. }\end{array}$ & $\begin{array}{l}\text { appropria } \\
\text { INC., } 2000 \\
\text { n the mod }\end{array}$ & $\begin{array}{l}\text { F-tests ge } \\
\sigma_{S}^{2}=\text { site }\end{array}$ & $\begin{array}{l}\text { erated by us } \\
\sigma^{2}{ }_{\mathrm{G}}=\text { below }\end{array}$ & $\begin{array}{l}\text { ing the "RANDOM" statem } \\
\text { ground GDD nested withi } \\
\sigma_{\mathrm{SC}}^{2}=\text { site*clone, } \sigma_{\mathrm{GC}}^{2}=\end{array}$ \\
\hline
\end{tabular}


Table 4. - Top dry weight and total dry weight (adjusted for cutting dry weight) of each combination of clone and belowground growing degree days of two populations of Populus $[P$. deltoides ' $\mathrm{D}$ ' and $\{P$. deltoides $\times$ P. maximowiczii $\}$ 'DM'] when planted as dormant hardwood cuttings. Standard errors are listed in parentheses.

\begin{tabular}{|c|c|c|c|c|c|c|c|}
\hline \multirow[b]{2}{*}{ Clone } & \multicolumn{7}{|c|}{ Belowground growing degree days } \\
\hline & 84 & 126 & 249 & 257 & 272 & 294 & Overall $^{\mathrm{a}}$ \\
\hline & \multicolumn{7}{|c|}{ Top dry weight (mg) } \\
\hline D133 & $95.58(32.42)$ & $69.55(32.44)$ & $7.48(32.73)$ & $40.14(32.86)$ & $205.79(32.76)$ & $92.55(32.54)$ & $85.18(13.72) \mathrm{a}$ \\
\hline D134 & $183.78(32.40)$ & $108.77(32.88)$ & $70.73(32.39)$ & $95.32(32.61)$ & $224.05(32.55)$ & $121.73(32.50)$ & $134.06(13.30) \mathrm{b}$ \\
\hline D Mean & $139.68(32.41)$ & $89.16(32.66)$ & $39.11(32.56)$ & $67.73(32.74)$ & $214.92(32.66)$ & $107.14(32.52)$ & $109.62(32.59)$ \\
\hline DM101 & $179.20(32.39)$ & $133.06(32.39)$ & $157.70(32.41)$ & $183.51(32.56)$ & $171.39(32.51)$ & $134.49(32.39)$ & $159.89(13.27) b$ \\
\hline DM105 & $221.17(32.39)$ & $217.86(32.40)$ & $178.73(32.64)$ & $173.52(32.65)$ & $269.00(32.54)$ & $199.33(32.61)$ & $209.94(13.23) \mathrm{c}$ \\
\hline $\mathrm{NC} 14105$ & $195.59(32.43)$ & $271.07(32.75)$ & $235.88(32.45)$ & $249.46(32.48)$ & $324.94(32.65)$ & $213.84(32.39)$ & $248.47(13.38) \mathrm{d}$ \\
\hline $\mathrm{NC} 14107$ & $188.46(33.08)$ & $208.24(32.40)$ & $157.45(32.51)$ & $270.71(32.39)$ & $344.92(32.60)$ & $206.82(32.39)$ & $229.43(13.30) \mathrm{cd}$ \\
\hline \multirow[t]{2}{*}{ DM Mean } & $196.11(32.57)$ & $207.56(32.49)$ & $182.44(32.50)$ & $219.30(32.52)$ & $277.56(32.57)$ & $188.62(32.44)$ & $211.93(32.52)$ \\
\hline & \multicolumn{7}{|c|}{ Total dry weight (mg) } \\
\hline D133 & $103.23(35.79)$ & $73.53(35.81)$ & $24.16(36.13)$ & $45.12(36.28)$ & $225.38(36.17)$ & $109.59(35.93)$ & $96.84(15.15) \mathrm{a}$ \\
\hline D134 & $200.47(35.76)$ & $116.45(36.30)$ & $76.51(35.76)$ & $106.90(36.00)$ & $251.53(35.94)$ & $133.76(35.88)$ & $147.60(14.68) b$ \\
\hline D Mean & $151.85(35.78)$ & $94.99(36.06)$ & $50.34(35.94)$ & $76.01(36.14)$ & $238.46(36.05)$ & $121.68(35.90)$ & $122.22(35.98)$ \\
\hline DM101 & $197.12(35.75)$ & $147.09(35.75)$ & $180.77(35.77)$ & $190.33(35.95)$ & $179.43(35.89)$ & $138.00(35.75)$ & $172.12(14.65) b$ \\
\hline DM105 & $252.59(35.75)$ & $254.05(35.77)$ & $185.64(36.03)$ & $188.28(36.04)$ & $278.77(35.92)$ & $210.36(36.00)$ & $228.28(14.60) \mathrm{c}$ \\
\hline $\mathrm{NC} 14105$ & $205.57(35.80)$ & $312.91(36.16)$ & $268.89(35.83)$ & $270.69(35.85)$ & $337.04(36.05)$ & $221.61(35.75)$ & $269.45(14.77) \mathrm{d}$ \\
\hline $\mathrm{NC} 14107$ & $216.38(36.51)$ & $273.27(35.77)$ & $202.42(35.89)$ & $312.94(35.75)$ & $374.18(35.99)$ & $232.84(35.76)$ & $268.67(14.68) \mathrm{cd}$ \\
\hline DM Mean & $217.92(35.95)$ & $246.83(35.86)$ & $209.43(35.88)$ & $240.56(35.90)$ & $292.36(35.96)$ & $200.70(35.82)$ & $234.63(35.90)$ \\
\hline
\end{tabular}

a Overall individual-clone means followed by the same letter are not different (top dry weight: $\mathrm{LSD}=36.78, \alpha=0.05, \mathrm{n}=60 ;$ total dry weight: $\operatorname{LSD}=40.61, \alpha=0.05, \mathrm{n}=60$ ).

and 0.19 , respectively. Phenotypic correlations ranged from 0.36 (number of roots with top dry weight) to 0.99 (top dry weight with total dry weight) (Table 1). Genotypic correlations ranged from 0.79 (root dry weight with top dry weight) to 1.00 (top dry weight with total dry weight), and environmental correlations ranged from 0.22 (number of roots with top dry weight) to 0.99 (top dry weight with total dry weight) (Table 2).

The main effect of clone was the most important factor influencing top dry weight and total dry weight. Clones differed for top dry weight and total dry weight $(P=0.0082, P=0.0073$, respectively) (Table 3). Overall, top dry weight and total dry weight of the $P$. deltoides $\times P$. maximowiczii clones nearly doubled that of the P. deltoides clones (Table 4). The interaction between belowground GDD and clone was negligible for top dry weight and total dry weight $(P=0.1692, P=0.1187$, respectively) (Table 3). Neither linear nor curvilinear regressions of top dry weight and total dry weight on belowground GDD were significant, resulting in the inability to identify a trend between these variables.

The main effect of clone and the interaction between belowground GDD and clone were the most important factors influencing root dry weight and number of roots. Clones differed for root dry weight and number of roots $(P=0.02, P=0.0208$, respectively) (Table 3). Overall, root dry weight of the hybrids nearly doubled that of the cottonwoods $(22.7 \pm 7.03 \mathrm{mg}$, 12.6 ! $7.05 \mathrm{mg}$, respectively). Likewise, number of roots of the hybrids doubled that of the cottonwoods $(10.68 \pm 1.93,5.4 \pm$ 1.94, respectively). The interaction between belowground GDD and clone was significant for root dry weight and number of roots $(P=0.0008, P<0.0001$, respectively) (Table 3 ). Root dry weight of the hybrids was nearly twice as much as that for the cottonwoods at the earliest planting date, while the number of roots after the first growing period for the hybrids was almost three and a half times that of the cottonwoods (Table 5). However, root dry weight and number of roots decreased for the hybrids and increased for the cottonwoods with later planting dates. Root dry weight of the hybrids was lower than the cottonwoods at the end of the experiment despite a slight hybridadvantage for number of roots over the cottonwoods (Table 5).

Belowground GDD increased with planting date across both sites (105, 253, 283, respectively). Least-squares regression analysis was used to examine the relationship between belowground GDD and root dry weight for both populations. A quadratic function was significant $(P=0.0372)$ with a coefficient of 
Table 5. - Root dry weight and number of roots (adjusted for cutting dry weight) of each combination of clone and belowground growing degree days of two populations of Populus $[P$. deltoides ' $\mathrm{D}$ ' and $\{P$. deltoides $\times$ P. maximowiczii\} 'DM'] when planted as dormant hardwood cuttings. Standard errors are listed in parentheses.

\begin{tabular}{|c|c|c|c|c|c|c|}
\hline \multirow[b]{2}{*}{ Clone } & \multicolumn{6}{|c|}{ Belowground growing degree days } \\
\hline & 84 & 126 & 249 & 257 & 272 & 294 \\
\hline & \multicolumn{6}{|c|}{ Root dry weight (mg) } \\
\hline D133 & $7.66(7.01)$ & $3.98(7.01)$ & $16.68(7.07)$ & $4.98(7.10)$ & $19.59(7.08)$ & $17.04(7.03)$ \\
\hline D134 & $16.69(7.00)$ & $7.68(7.11)$ & $5.78(7.00)$ & $11.58(7.05)$ & $27.47(7.04)$ & $12.03(7.02)$ \\
\hline D Mean & $12.18(7.01)$ & $5.83(7.06)$ & $11.23(7.04)$ & $8.28(7.08)$ & $23.53(7.06)$ & $14.54(7.03)$ \\
\hline DM101 & $17.92(7.00)$ & $14.03(7.00)$ & $23.07(7.00)$ & $6.82(7.04)$ & $8.04(7.03)$ & $3.52(7.00)$ \\
\hline DM105 & $31.42(7.00)$ & $36.19(7.00)$ & $6.91(7.05)$ & $14.76(7.06)$ & $9.78(7.03)$ & $11.02(7.05)$ \\
\hline $\mathrm{NC} 14105$ & $9.98(7.01)$ & $41.84(7.08)$ & $33.00(7.01)$ & $21.24(7.02)$ & $12.10(7.06)$ & $7.76(7.00)$ \\
\hline $\mathrm{NC} 14107$ & $27.92(7.15)$ & $65.03(7.00)$ & $44.97(7.03)$ & $42.23(7.00)$ & $29.26(7.05)$ & $26.03(7.00)$ \\
\hline \multirow[t]{2}{*}{ DM Mean } & $21.81(7.04)$ & $39.27(7.02)$ & $26.99(7.02)$ & $21.26(7.03)$ & $14.80(7.04)$ & $12.08(7.01)$ \\
\hline & \multicolumn{6}{|c|}{ Number of roots } \\
\hline D133 & $5.02(1.93)$ & $4.17(1.93)$ & $12.35(1.94)$ & $4,85(1.95)$ & $8.52(1.95)$ & $2.72(1.93)$ \\
\hline D134 & $2.00(1.92)$ & $4.77(1.95)$ & $3.28(1.92)$ & $4.85(1.94)$ & $9.71(1.93)$ & $2.52(1.93)$ \\
\hline D Mean & $3.51(1.93)$ & $4.47(1.94)$ & $7.81(1.93)$ & $4.85(1.95)$ & $9.12(1.94)$ & $2.62(1.93)$ \\
\hline DM101 & $10.25(1.92)$ & $11.45(1.92)$ & $13.14(1.93)$ & $6.79(1.93)$ & $3.63(1.93)$ & $3.45(1.92)$ \\
\hline DM 105 & $9.53(1.92)$ & $20.03(1.93)$ & $8.43(1.94)$ & $7.78(1.94)$ & $8.33(1.93)$ & $4.55(1.94)$ \\
\hline $\mathrm{NC} 14105$ & $10.61(1.93)$ & $21.37(1.95)$ & $10.44(1.93)$ & $10.49(1.93)$ & $5.59(1.94)$ & $2.26(1.92)$ \\
\hline $\mathrm{NC} 14107$ & $18.02(1.97)$ & $21.77(1.93)$ & $13.53(1.93)$ & $15.96(1.92)$ & $11.97(1.94)$ & $7.07(1.92)$ \\
\hline DM Mean & $12.10(1.94)$ & $18.65(1.93)$ & $11.38(1.93)$ & $10.26(1.93)$ & $7.38(1.94)$ & $4.33(1.93)$ \\
\hline
\end{tabular}

determination of $r^{2}=0.88$ when fit to the data of root dry weight on belowground GDD for the hybrids. A similar analysis for the cottonwoods resulted in a non-significant quadratic function $(P=0.4057)$ with a coefficient of determination of $r^{2}=$ 0.39 , which was greater than that for the linear model $\left(r^{2}=\right.$ 0.20). Thus, the quadratic functions fit both datasets better than the linear models. There was an inverse relationship between root dry weight and belowground GDD for the hybrids, while root dry weight increased with increasing belowground GDD for the cottonwoods (Figure 2).

\section{Discussion}

Our data illustrated broad variation in belowground temperatures across Julian dates. The erratic nature of these temperatures at $20 \mathrm{~cm}$ below the soil surface supported the need for the identification of a suitable thermal index. Our established index should be used to schedule planting for conditions of belowground temperatures that promote rooting, based on the genotype deployed. We have successfully implemented a thermal index based on the accumulation of belowground GDD that is more biologically meaningful than protocols basing the time of planting on calendar days (LU et al., 2001; LUOMAJOKI, 1995). Our GDD-based thermal index was sensitive to erratic belowground temperatures, while being straightforward and easy to develop.
In addition to carbohydrate reserves in the cuttings (FEGE and BROWN, 1984), our results agreed with others that the initiation and growth of roots depended on how the cuttings responded to an environmental stimulus such as soil temperature (DEsRochers et al., 2002; LANDHÄUSSER et al., 2001; WAN

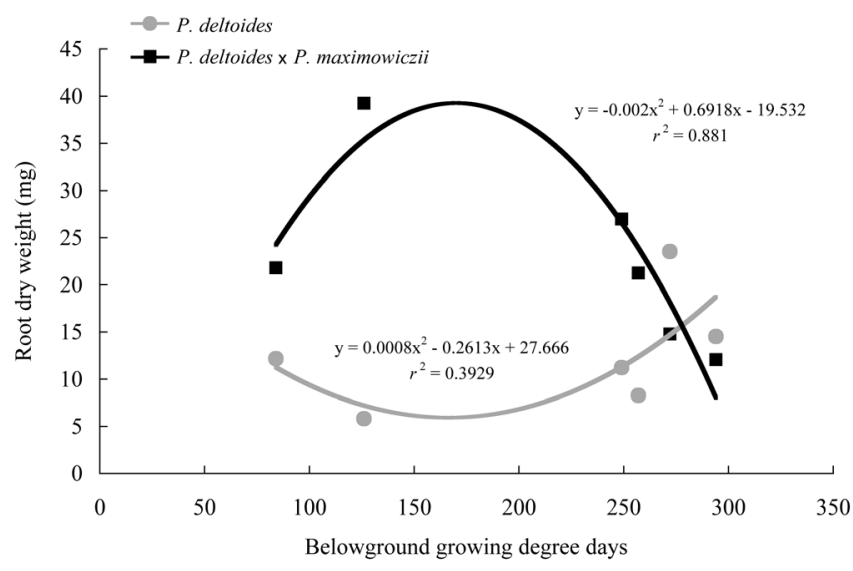

Figure 2. - Least-squares regression analysis of root dry weight on belowground growing degree days of two populations of Populus [P. deltoides 'D' and $\{P$. deltoides $\times$ P. maximowiczii $\}$ 'DM'] when planted as dormant hardwood cuttings. Each point represents the mean of 20 cuttings for the D clones and the mean of 40 cuttings for the DM clones. 
et al., 1999). Other soil characteristics such as moisture and strength also may have affected the rooting (HARVEY and VAN DEN Driessche, 1999; Tschaplinski et al., 1998; Wiersum, 1980); however, our objectives did not warrant the evaluation of such stimuli. We recommend conducting future studies under controlled environments to test for the effects of various soil conditions on rooting.

We believe our GDD-based thermal index and its inclusion as a classification variable for belowground GDD in our model allowed us to isolate substantial variation associated with environmental error. Our broad-sense heritability estimates of 0.15 and 0.19 for root dry weight and number of roots, respectively, were greater than previous field studies $(H<0.10)$ (ZALESNY, 2003; ZALESNY et al., 2003); however, the heritability estimates from most previous studies that were conducted in growth chambers and greenhouses were greater than ours because environmental error was further reduced ( $H$ from 0.15 to 0.80 , FARMER et al., 1989; $H$ from 0.36 to 0.56 , WILCOX and FARMER, $1967 ; H>0.80$, YING and BAGLEY, 1977). Although our GDD index reduced the variation associated with environmental error compared with other field studies, we believe our heritability estimates were lower than those of previous controlledenvironment studies due to greater variation from changing environmental conditions such as soil moisture, soil strength, wind, and solar radiation. Furthermore, the heritability estimates of 0.18 and 0.19 for top dry weight and total dry weight, respectively, were lower than in previous studies $(H>0.30)$ and expressed that environmental variation decreased using our GDD index. The overall variation due to the interaction of belowground GDD and clone was greater for top dry weight and total dry weight than for the rooting traits because less relative variation was isolated, which resulted in an increased denominator in the heritability model than is typically estimated for aboveground traits. For example, broad-sense heritabilities as great as 0.94 have been reported for aboveground traits of poplars (RIEMENSCHNEIDER et al., 1994; 1992; WU and SteTtLer, 1994).

Our phenotypic correlations corroborated those of previous studies (ZALESNY, 2003; RIEMENSCHNEIDER and BAUER, 1997). We agree with RIEMENSCHNEIDER and BAUER (1997) that only a few easily measured dependent variables need to be studied to learn about the aboveground and belowground growth of the cuttings without losing substantial biological information. Our genotypic correlations and environmental correlations, when evaluating parallel plant growth and development systems, supported this assertion. For example, given the environmental correlation of $r_{\mathrm{E}}=0.62$ between root dry weight and number of roots, we could expect similar rooting responses under changing environments.

Differences among clones for aboveground growth were mostly genetic. Genotype $x$ environment interactions were negligible for top dry weight and total dry weight. In contrast, genotype $x$ environment interactions for height growth and other aboveground traits of $P$. deltoides and $P$. balsamifera have been reported (KNOwE et al., 1998; RIEMENSCHNEIDER and MCMAHON, 1993, respectively). Likewise, diameter at breast height of 6year-old pure $P$. deltoides and poplar hybrids $(P$. deltoides $\mathrm{x}$ $P$. maximowiczii, $P$. deltoides $\times P$. nigra, $P$. nigra $\times P$. maximowiczii, and $P$. alba $\times$ P. grandidentata) also have depended on genotype $x$ environment interactions (RIEMENSCHNEIDER et al., 2001), along with architectural components of crown structure in a cloned interspecific hybrid pedigree of $P$. trichocarpa and P. deltoides (WU and STETTLER, 1998). However, given the objectives of our study, we expected negligible interactions between belowground GDD and clone due to minimal direct influence of soil temperatures on aboveground growth. There may have been indirect influence of top growth as number of roots and root size increased; however, we believe $14 \mathrm{~d}$ is too short to observe such vicarious effects. Nevertheless, separating the clone means using Fisher's protected LSD produced three different groups based on top dry weight and total dry weight. The aforementioned controlled environment studies could be used with systems of different aboveground and belowground temperatures, which may lead to genotype $\mathrm{x}$ environment interactions for aboveground growth similar to those in previous studies.

\section{Conclusion}

The interaction between belowground GDD and clone governed root dry weight and number of roots across sites. Although a belowground temperature of $10^{\circ} \mathrm{C}$ is generally accepted as a threshold for planting poplars (LANDHÄUSSER et al., 2001; WAN et al., 1999; HANSEN et al., 1983), reported information lacks recommendations for planting specific genotypes at various soil temperatures. To our knowledge, there are no reported results recommending planting of poplars based on a thermal index such as the accumulation of belowground GDD. Our results indicated the need for such recommendations because we observed different rooting responses between cottonwoods and hybrids across Julian dates. Warmer soil temperatures promoted rooting for the cottonwoods while relatively cooler temperatures promoted rooting for the hybrids. Assuming a base temperature of $10^{\circ} \mathrm{C}$, we recommend planting after reaching a threshold of 163 belowground GDD for $P$. deltoides clones and planting before reaching a threshold of 173 belowground GDD for $P$. deltoides $\times$ P. maximowiczii clones.

\section{Acknowledgements}

This research was funded by the USDA Forest Service North Central Research Station and the Minnesota Hybrid Poplar Research Cooperative. We are grateful to the following people for review of earlier versions of the manuscript: RоB DOUDRICK, Bill Headlee, Assibi Mahama, Adam Wiese and Jill Zalesny.

\section{Literature Cited}

Castelan-Estrada, M., Vivin, P. and Gaudillere, J. P. (2002): Allometric relationships to estimate seasonal above-ground vegetative and reproductive biomass of Vitis vinifera L. Ann. Bot. 89: 401-408.

Cox, R. M. and Malcolm, J.W. (1997): Effects of duration of a simulated winter thaw on dieback and xylem conductivity of Betula papyrifera. Tree Physiol. 17: 389-396.

CunNinghaM, F. E. (1953): Rooting ability of native cottonwoods depends on the clone used. USDA For. Serv. Res. Note NWRN-2.

DesRochers, A., Landhäusser, S. M. and Lieffers, V. J. (2002): Coarse and fine root respiration in aspen (Populus tremuloides). Tree Physiol. 22: 725-732.

Dickmann, D. I. (2001): An overview of the genus Populus, pp. 1-42. In: D. I. DickmanN, J. G. Isebrands, J. E. ECKENWALDER, and J. RichARDSON (eds.). Poplar culture in North America. Part A, Chapter 1. NRC Research Press, National Research Council of Canada, Ottawa, Ontario, Canada.

FALCONER, D. S. and MACKAY, T. F. C. (1989): Introduction to quantitative genetics. Fourth Edition, Longman Scientific and Technical, Essex, England.

Farmer, R. E., JR., Freitag, M. and Garlick, K. (1989): Genetic variance and "C" effects in balsam poplar rooting. Silvae Genet. 38: 62-65.

Fege, A. S. and Brown, G. N. (1984): Carbohydrate distribution in dormant Populus shoots and hardwood cuttings. For. Sci. 30: $999-1010$.

Haissig, B. E., Davis, T. D. and RiEmenschneider, D. E. (1992): Researching the controls of adventitious rooting. Physiol. Plant. 84: 310-317. 
Hansen, E. A. (1986): Planting date affects survival and height growth of hybrid poplar. For. Chron. 62: 164-169.

Hansen, E. A., Moore, L., Netzer, D. A., Ostry, M., Phipps, H. and ZAVITKOVsKI, J. (1983): Establishing intensively cultured hybrid poplar plantations for fuel and fiber. USDA For. Serv. Gen. Tech. Rep. NC-GTR-78.

HARveY, H. P. and van DEN DRIEssche, R. (1999): Poplar nutrient resorption in fall or drought: influence of nutrient status and clone. Can. J. For. Res. 29: 1916-1925.

HeIlman, P. E. (1999): Planted forests: poplars. New Forests 17: 89-93.

Heilman, P. E., Ekuan, G. and Fogle, D. B. (1994): Above- and below-ground biomass and fine roots of 4-year-old hybrids of Populus trichocarpa $\times$ Populus deltoides and parental species in short-rotation culture. Can. J. For. Res. 24: 1186-1192.

Husain, S. A., Rose, D. W. and ARChibald, S. O. (1998): Identifying agricultural sites for biomass energy production in Minnesota. Biomass Bioenergy 15: 423-435.

IsEBRANDS, J. G. and KARNOSKY, D. F. (2001): Environmental benefits of poplar culture, pp. 207-218. In: D. I. DiCKMANN, J. G. IsEbrands, J. E. ECKENWALDER and J. RICHARDSON (eds.). Poplar culture in North America. Part A, Chapter 6. NRC Research Press, National Research Council of Canada, Ottawa, Ontario, Canada.

JENKINSON, J. L. (1980): Improving plantation establishment by optimizing growth capacity and planting time of western yellow pines. USDA For. Serv. Res. Pap. PSW-RP-154.

Knowe, S. A., Foster, G. S., Rousseau, R. J. and Nance, W. L. (1998): Height-age and height-diameter relationships for monocultures and mixtures of eastern cottonwood clones. For. Ecol. Manage. 106: 115-123.

LandhäUsser, S. M., DesRochers, A. and Liefferer, V. J. (2001): A comparison of growth and physiology in Picea glau$c a$ and Populus tremuloides at different soil temperatures. Can. J. For. Res. 31: 1922-1929.

Lobit, P., SoInG, P., Genard, M. and HaBib, R. (2001): Effects of timing of nitrogen fertilization on shoot development in peach (Prunus persica) trees. Tree Physiol. 21: 35-42.

Lu, H. Y., Lu, C. T., ChAN, L. F. and WeI, M. L. (2001): Seasonal variation in linear increase of taro harvest index explained by growing degree days. Agron. J. 93: 1136-1141.

LUOMAJOKI, A. J. (1995): Phenological measurements of microsporogenesis in trees. Tree Physiol. 15: 499-505.

Newman, J. E., Blair, B. O., Dale, R. F., Smith, L. H., Stirm, W. L. and SchaAL, L. A. (1968): Growing degree days. Crops Soils December: 9-12.

PIVA, R. J. (2003): Pulpwood production in the North-Central Region, 1999. USDA For. Serv. Resour. Bul. NC-RB-214.

Rhodenbaugh, E. J. and PAllardy, S. G. (1993): Water stress, photosynthesis and early growth patterns of cuttings of three Populus clones. Tree Physiol. 13: 213-226.

RIEMENSChNeIder, D. E. and BAUer, E. O. (1997): Quantitative genetic analysis of adventitious root forming ability in Populus trichocarpa (TORR ET. GRAY), pp. 193-201. In: ALTMAN and WAISEL (eds). Biology of Root Formation and Development. Chapter 24. Plenum Press, New York.

Riemenschneider, D. E., Berguson, W. E., Dickmann, D. I., Hall, R. B., Isebrands, J. G., Mohn, C. A., Stanosz, G. R. and Tuskan, G. A. (2001): Poplar breeding and testing strate- gies in the north-central U.S.: demonstration of potential yield and consideration of future research needs. For. Chron. 77: $245-253$.

Riemenschneider, D. E. and McMahon, B. G. (1993): Genetic variation among Lake States balsam poplar populations is associated with geographic origin. For. Sci. 39: 130-136.

Riemenschneider, D. E., McMahon, B. G. and Ostry, M. E. (1992): Use of selection indices to increase tree height and to control damaging agents in 2-year-old balsam poplar. Can. J. For. Res. 22: 561-567.

Riemenschneider, D. E., McMahon, B. G. and Ostry, M. E. (1994): Population-dependent selection strategies needed for 2-year-old black cottonwood clones. Can. J. For. Res. 24: $1704-1710$

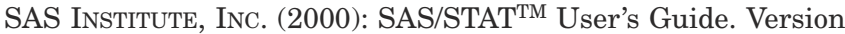
8. Cary, North Carolina, SAS Institute, Inc.

Stanturf, J. A., van Oosten, C., Netzer, D. A., Coleman, M. D. and PorTwood, C. J. (2001): Ecology and silviculture of poplar plantations, pp. 153-206. In: D. I. DiCKMANN, J. G. IsEbrandS, J. E. ECKENWALDER, and J. RICHARDSON (eds). Poplar culture in North America. Part A, Chapter 5. NRC Research Press, National Research Council of Canada, Ottawa, Ontario, Canada.

Tolbert, V. R. and Wright, L. L. (1998): Environmental enhancement of U.S. biomass crop technologies: research results to date. Biomass Bioenergy 15: 93-100.

Tschaplinski, T. J., Tuskan, G. A., Gebre, G. M. and Todd, D. E. (1998): Drought resistance of two hybrid Populus clones grown in a large-scale plantation. Tree Physiol. 18: 653-658.

Vinocur, M. G. and Ritchie, J. T. (2001): Maize leaf development biases caused by air-apex temperature differences. Agron. J. 93: 767-772.

WAN, X., LANDHÄUsser, S. M., ZwiazeK, J. J. and LiefFers, V. J. (1999): Root water flow and growth of aspen (Populus tremuloides) at low root temperatures. Tree Physiol. 19: 879-884.

WiERSUM, L. K. (1980): The effect of soil physical conditions on roots and uptake. Acta Hort. 92: 111-122.

WILCOX, J. R. and FARMER, R. E., JR. (1967): Variation and inheritance of juvenile characters of eastern cottonwood. Silvae Genet. 16: 162-165.

WILCOX, J.R. and FARMER, R. E., JR. (1968): Heritability and C effects in early root growth of eastern cottonwood cuttings. Heredity 23: 239-245.

Wu, R.-L. and STETTLER, R. F. (1994): Quantitative genetics of growth and development in Populus. I. A three-generation comparison of tree architecture during the first two years of growth. Theor. Appl. Genet. 89: 1046-1054.

Wu, R.-L. and StETTLER, R. F. (1998): Quantitative genetics of growth and development in Populus. III. Phenotypic plasticity of crown structure and function. Heredity 81: 299-310.

YING, C. C. and BAGLeY, W. T. (1977): Variation in rooting capability of Populus deltoides. Silvae Genet. 26: 204-207.

ZALESNY, R. S., JR. (2003): Genetic and environmental effects on rooting ability of dormant unrooted hybrid poplar cuttings. PhD Dissertation, Iowa State Univ., Ames, Iowa.

Zalessny, R. S., JR., Hall, R. B., BAuer, E. O. and RiemenSCHNEIDER, D. E. (2003): Shoot position affects root initiation and growth of dormant unrooted cuttings of Populus. Silvae Genet. 52: 273-279. 